\title{
New stent design for use in small coronary arteries during percutaneous coronary intervention
}

This article was published in the following Dove Press journal:

Medical Devices: Evidence and Research

15 October 2010

Number of times this article has been viewed

\author{
Juan F Granada' \\ Barbara A Huibregtse ${ }^{2}$ \\ Keith D Dawkins² \\ 'The Jack H Skirball Center \\ for Cardiovascular Research, \\ Cardiovascular Research \\ Foundation, Columbia University \\ Medical Center, New York, NY, USA; \\ ${ }^{2}$ Boston Scientific Corporation, \\ Natick, MA, USA
}

\begin{abstract}
Patients with diabetes mellitus, of female gender, increased age, and/or with peripheral vascular disease often develop coronary stenoses in small caliber vessels. This review describes treatment of these lesions with the paclitaxel-eluting $2.25 \mathrm{~mm} \mathrm{TAXUS}^{\circledR}$ Liberté $^{\circledR}$ Atom $^{\mathrm{TM}}$ stent. Given the same stent composition, polymer, antirestenotic drug (paclitaxel), and release kinetics as the first-generation $2.25 \mathrm{~mm}$ TAXUS ${ }^{\circledR}$ Express $^{\circledR}$ Atom ${ }^{\mathrm{TM}}$ stent, the second-generation TAXUS Liberté Atom stent incorporates improved stent design characteristics, including thinner struts ( 0.0038 versus 0.0052 inches), intended to increase conformability and deliverability. In a porcine noninjured coronary artery model, TAXUS Liberté Atom stent implantation in small vessels demonstrated complete strut tissue coverage compared with the bare metal stent control, suggesting a similar degree of tissue healing between the groups at 30, 90, and 180 days. The prospective, single-armed TAXUS ATLAS Small Vessel trial demonstrated improved instent late loss $(0.28 \pm 0.45$ versus $0.84 \pm 0.57 \mathrm{~mm}, P<0.001)$, instent binary restenosis $(13.0 \%$ versus $38.1 \%, P<0.001)$, and target lesion revascularization $(5.8 \%$ versus $17.6 \%, P<0.001)$ at nine months with the TAXUS Liberté Atom stent as compared with the bare metal Express stent control, with similar safety measures between the two groups. The TAXUS Liberte Atom also significantly reduced nine-month angiographic rates of both instent late loss $(0.28 \pm 0.45$ versus $0.44 \pm 0.61 \mathrm{~mm}, P=0.03)$ and instent binary restenosis $(13.0 \%$ versus $25.9 \%, P=0.02)$ when compared with the $2.25 \mathrm{~mm}$ TAXUS Express Atom control. The observed reduction in target lesion revascularization with the TAXUS Liberté Atom compared with the TAXUS Express Atom at nine months $(5.8 \%$ versus $13.7 \%, P=0.02)$ was sustained through three years ( $10.0 \%$ versus $22.1 \%, P=0.008$ ) with similar, stable safety outcomes between the groups. In conclusion, these data confirm the safety and favorable performance of the TAXUS Liberte Atom stent in the treatment of small coronary vessels.
\end{abstract}

Keywords: small vessel, paclitaxel, stent

\section{Introduction}

Treatment of small vessels, historically defined as $<3.0 \mathrm{~mm}$ in diameter, constitutes an estimated $30 \%-50 \%$ of all percutaneous coronary interventions. ${ }^{1,2}$ As interventional practice has developed, vessels $<2.5$ to $2.75 \mathrm{~mm}$ by visual estimate are currently considered to be small vessels. ${ }^{3}$ Female gender, diabetes mellitus, increased age, and peripheral vascular disease are often associated with small vessel coronary atherosclerotic lesions. ${ }^{4-6}$ The increasing prevalence of diabetes, along with prolonged life expectancy, will likely increase the number of small coronary vessels requiring treatment. Although the use of bare metal stents versus plain balloon angioplasty has reduced restenosis and major adverse cardiac events among patients undergoing percutaneous coronary intervention in coronary vessels $\geq 3.0 \mathrm{~mm},{ }^{7,8}$ several studies 
comparing bare metal stenting versus balloon angioplasty in small vessels have demonstrated conflicting and inconclusive clinical and angiographic results. ${ }^{9-11}$ The introduction of drug-eluting stents in the treatment of small coronary vessels has shown favorable and improved outcomes in this high-risk subgroup of patients. ${ }^{12-16}$ This review examines the use of the paclitaxel-eluting TAXUS ${ }^{\circledR}$ Liberté $^{\circledR}$ Atom $^{\text {TM }} 2.25$ mm stent in the treatment of very small coronary vessels $(2.25-2.5 \mathrm{~mm}$ vessel diameter).

\section{Challenges of small vessel stent implantation}

Performing interventional procedures on small vessels presents a number of technical challenges. Delivering a stent to a given lesion in a small vessel may be hampered by more difficult visualization, distal and branch vessel locations, vessel tortuosity, and greater lesion complexity, including calcification. Distal lesions are also more frequently diffuse, requiring longer, more flexible stents to cover the diseased segment.

Endothelial injury, as well as deeper arterial wall trauma, usually occurs following stent implantation. Injury stimulates excessive smooth muscle cell proliferation, with consequent migration into the intima, leading to neointimal hyperplasia, the primary mechanism of late lumen loss and instent restenosis. ${ }^{17,18}$

A comparison of clinical restenosis between bare metal and drug-eluting stents demonstrated a difference in the restenosis patterns, with a more focal restenosis in the drug-eluting stents compared with bare metal stents, and a higher incidence of bifurcation lesions in the drug-eluting cohort. Neointimal tissue within instent restenotic lesions was observed to be similar between drug-eluting stents and bare metal stents, and comprised mainly proteoglycan-rich smooth muscle cells and fibrolipidic areas rich in collagen and reticular fibers. Although no difference in smooth muscle cell proliferation rate was observed between drug-eluting stent and bare metal stent samples, the smooth muscle cell phenotype was characterized as contractile or intermediate in the drug-eluting stent samples, and synthetic phenotype in the bare metal stent samples, suggesting different mechanisms of restenosis. ${ }^{19}$

Although drug-eluting stents reduce neointimal hyperplasia and resulting late lumen loss compared with bare metal stents, lesions located in small vessels are more prone to develop hemodynamically significant restenosis compared with those in larger vessels. ${ }^{20,21} \mathrm{~A}$ possible explanation is that small vessels have a limited ability to accommodate lumen renarrowing after percutaneous coronary intervention, an outcome attenuated following implantation of a thinner strut stent. ${ }^{22}$ This may explain why no bare metal stent has received US Food and Administration (FDA) approval for vessels $\leq 2.5 \mathrm{~mm}$ in diameter. ${ }^{23}$ The combined challenges of deliverability, lesion complexity, and increased restenosis in smaller vessels highlight the need for dedicated stent systems to treat this ever-increasing subset of patients.

\section{TAXUS Liberté Atom stent system components Drug}

Paclitaxel, derived from the Pacific yew tree (Taxus brevifolia), delays restenosis by binding and stabilizing the assembly of microtubules, thereby arresting cellular replication in the $G_{0} / G_{1}$ and $G_{1} / M$ phases. ${ }^{24}$ In contrast, the -olimus (rapamycin) drugs diminish microtubule activity by inhibiting mTOR, a key intermediary in the PI-3-kinase pathway. ${ }^{25}$ In human arterial smooth muscle cells, paclitaxel binds $\beta$-tubulin dimers and inhibits their depolymerization resulting in stable microtubules. This nonfunctional assembly of microtubules disrupts a variety of cellular processes, resulting in the inhibition of smooth muscle cell migration and proliferation and, ultimately, neointimal hyperplasia and restenosis. ${ }^{26-28}$ Importantly, paclitaxel does not cause smooth muscle cell apoptosis. ${ }^{24}$ Paclitaxel is insoluble in water, which minimizes loss to the blood during stent implantation and facilitates tissue uptake when in contact with the arterial wall. The highly lipophilic nature of paclitaxel enhances cellular uptake, resulting in effective inhibition of neointimal formation. ${ }^{29}$

\section{Polymer}

The TAXUS Liberté Atom coronary stent uses a soft, hydrophobic, elastomeric triblock copolymer known as Translute ${ }^{\mathrm{TM}}$ (styrene-b-isobutylene-b-styrene). ${ }^{30}$ This polymer provides homogeneous coverage of paclitaxel along all stent surfaces, retention and protection of paclitaxel during routine handling of the stent, controlled local target delivery of paclitaxel, and long-term vascular compatibility. The TAXUS polymer formulation provides an early burst release of paclitaxel in the first 48 hours to blunt the initial response to implant injury, followed by a lower level of paclitaxel release for approximately 10 days to maintain this inhibited inflammatory response and yet allow for vascular healing.

\section{Stent}

The TAXUS Liberté Atom $2.25 \mathrm{~mm}$ stent evolved from the FDA-approved first-generation TAXUS Express Atom 
$2.25 \mathrm{~mm}$ stent (Boston Scientific Corporation, Natick, MA) with the aim of providing enhanced lesion access and more homogeneous drug distribution in small vessels. Both stents consist of a $316 \mathrm{~L}$ stainless steel stent coated with the Translute polymer containing paclitaxel in a dose density of $1 \mu \mathrm{g} / \mathrm{mm}^{2}$. The Liberté stent incorporates improved stent design characteristics intended to increase conformability and deliverability into more complex lesions including, multiangled thin struts ( 0.0038 versus 0.0052 inches) and the elimination of long straight joining connectors (Figure 1). Thinner struts have been associated with a lower late luminal loss and less neointimal volume obstruction after stenting, possibly a result of less stent-induced arterial injury and inflammation. ${ }^{31,32}$ The TAXUS Liberté Atom stent system features a low tip profile (0.017 inches) designed to cross tighter lesions, as well as a low stent crossing profile ( 0.041 inches), and a $13 \%$ more trackable stent delivery system as compared with the TAXUS Express $^{2}$ Atom stent system (data on file, Boston Scientific Corporation). The continuous cell design of the TAXUS Liberté Atom stent provides better vessel coverage and more uniform drug delivery along the length of the stent compared with the TAXUS Express Atom stent (Figure 2). The TAXUS Liberté Atom stent was designed to provide dedicated sizing for small vessels $(2.25-2.50 \mathrm{~mm})$ and is crimped on a balloon delivery catheter of a corresponding diameter.

\section{Preclinical testing}

Extensive safety testing was conducted using a porcine coronary artery model. ${ }^{33}$ Sixty small vessel stents (30 TAXUS Liberté Atom [paclitaxel-eluting stent] and 30 bare metal Liberté stents [bare metal]) were implanted in all three coronary arteries of 30 female domestic crossbred swine. Each animal
TAXUS Express

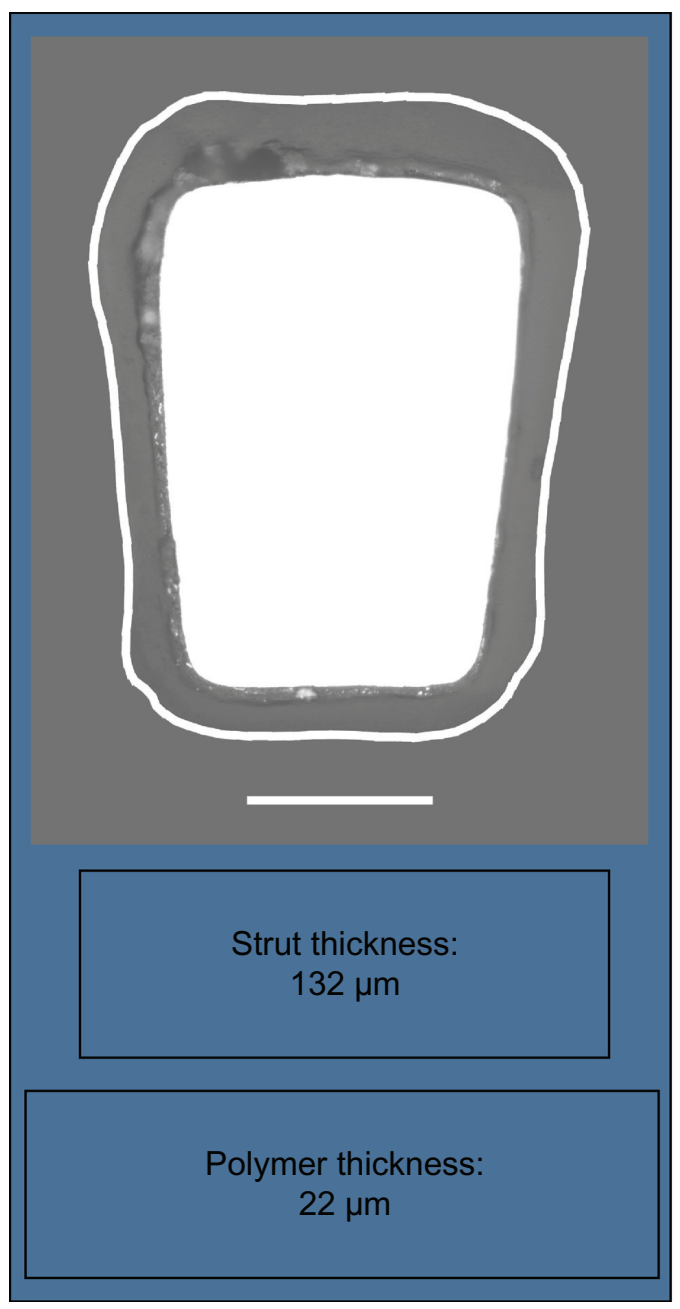

TAXUS Liberté

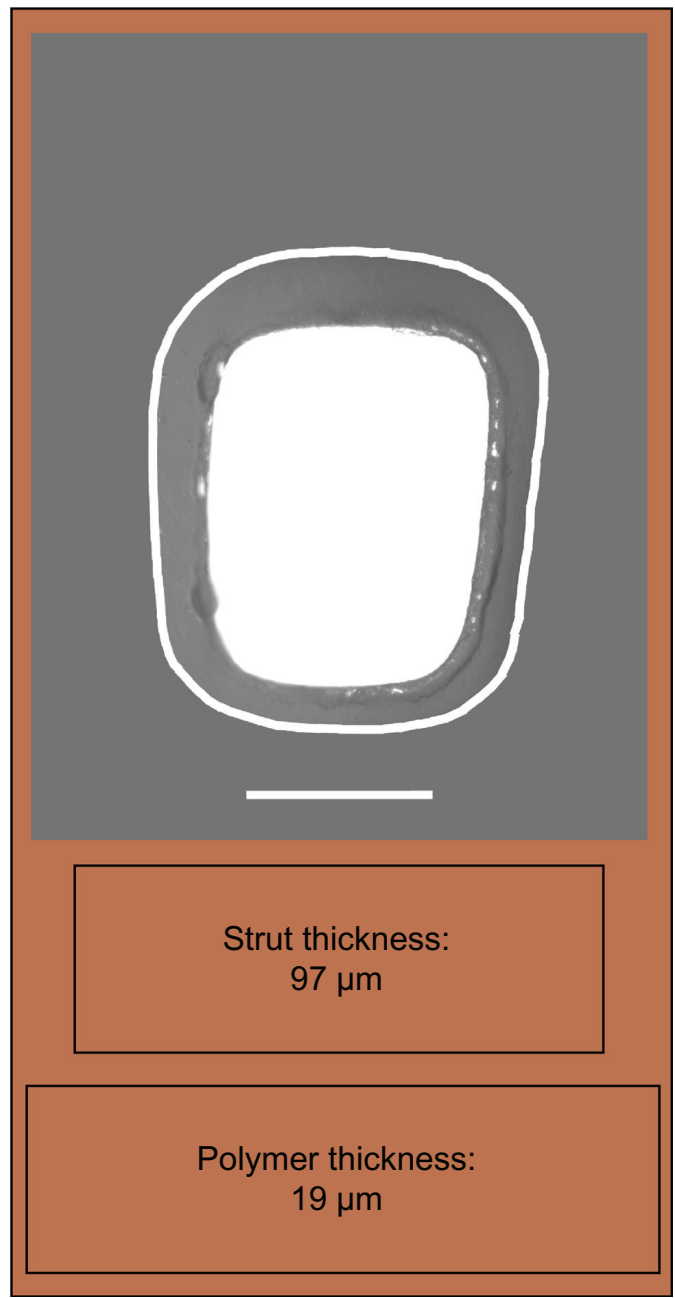

Figure I Study device strut and polymer thickness. Cross-sectional scanning electron micrograph images of the TAXUS Liberté Atom and TAXUS Express Atom stents with polymer edges outlined.

Notes: $500 \times$ magnification, bar $=50 \mu \mathrm{m}$. 


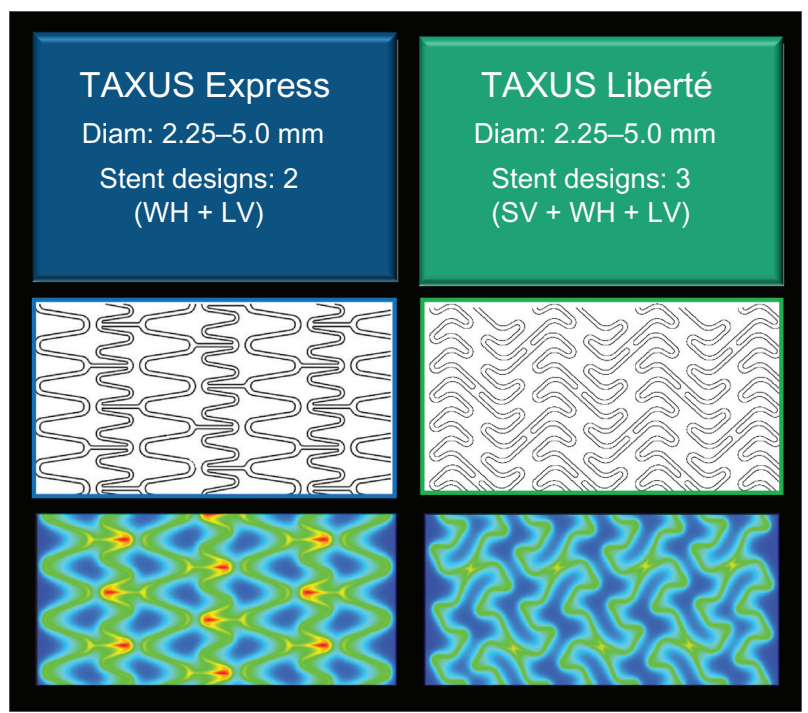

Figure 2 TAXUS paclitaxel-eluting stent designs. Improved stent-to-artery ratio and more homogeneous drug delivery with the TAXUS Liberte stent compared with the TAXUS Express stent.

Abbreviations: SV, small vessel; WH, workhorse; LV, large vessel.

received one test stent (paclitaxel-eluting stent, $2.0 \times 12 \mathrm{~mm}$ or $2.5 \times 20 \mathrm{~mm}$ ) and one control stent (bare metal stent, $2.25 \times 16 \mathrm{~mm}$ or $2.5 \times 16 \mathrm{~mm}$ ) in separate vessels. As shown in Figure 3, TAXUS Liberté Atom demonstrated greater than $90 \%$ endothelial cell strut coverage, as assessed by scanning electron microscopy and no visible evidence of luminal thrombi at 30, 90, and 180 days. Vascular compatibility using histologic analysis demonstrated complete strut tissue coverage, complete endothelialization, a small amount of fibrin deposition, and no adverse positive or negative remodeling in both groups at 30 days, and persisting out to 90 and 180 days (Figure 4). Since delayed healing has been associated with persistent fibrin deposition and reduced or delayed endothelialization in humans,${ }^{34}$ the vascular response supports the favorable safety profile of the TAXUS Liberté Atom stent compared with the bare metal stent control in a noninjured swine model.

\section{Clinical outcomes Clinical trials with TAXUS stents in small vessels}

The definition for small vessels varies in range from $<3.0 \mathrm{~mm}$ (historic definition) to anywhere from $<2.5$ to $2.75 \mathrm{~mm}$ as assessed by visual estimate. ${ }^{3}$ Since angiographic outcomes are affected by stent size and small vessel diameter, ${ }^{35,36}$ this review focuses on either the TAXUS Liberté Atom stent size $(2.25 \mathrm{~mm})$ or within its indicated reference vessel diameter ( $\leq 2.5 \mathrm{~mm}$ ). Small vessel subgroup analyses from three multicenter, randomized TAXUS trials, as well as a
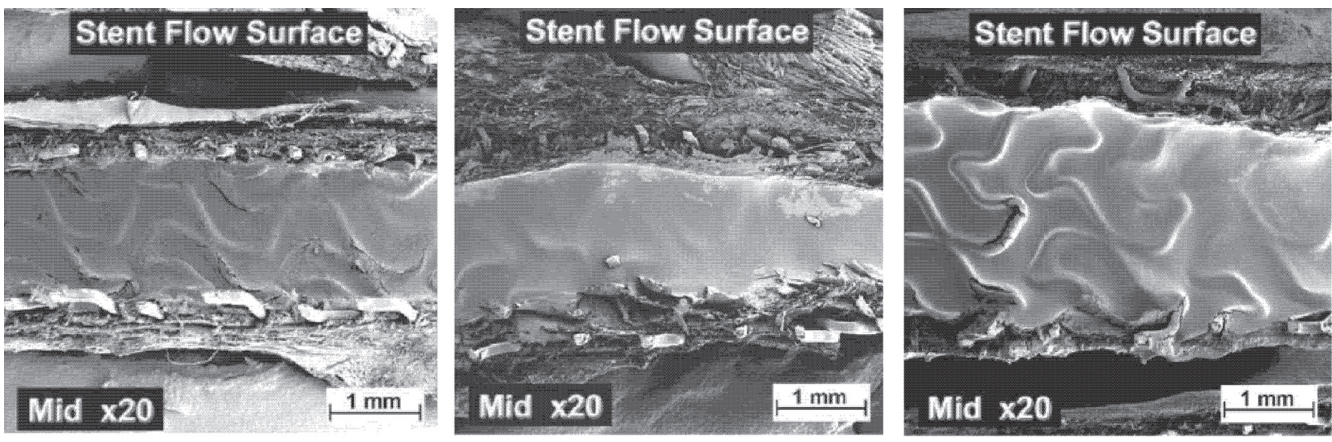

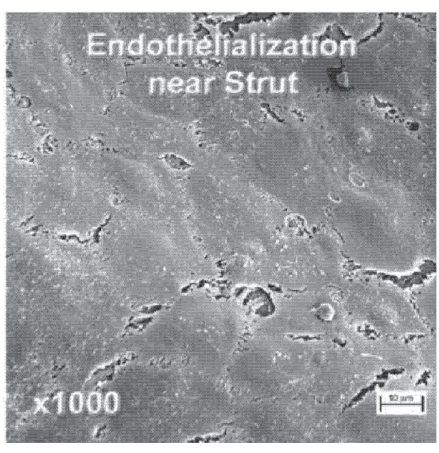

30 day 3P694 RCA

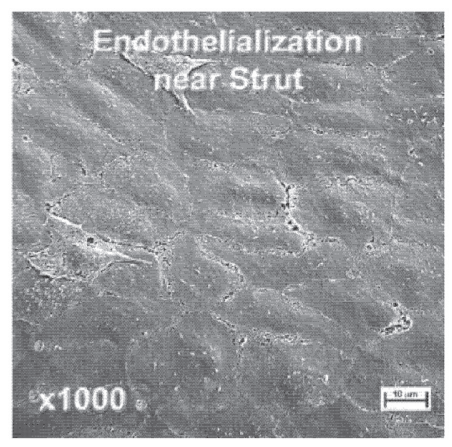

90 day 3P670 RCA

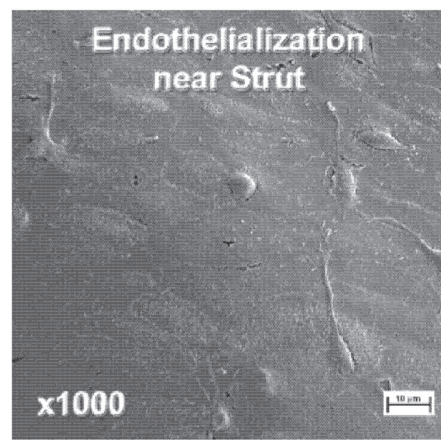

180 day 3 P708 LAD

Figure 3 Endothelialization of the TAXUS Liberté Atom stent in a noninjured porcine model. Representative scanning electron microscopy of the TAXUS. Liberte Atom stent platform in midstent segments at 30,90, and 180 days demonstrating strut coverage by tissue with cells of endothelial morphology comprising the flow surface. Copyright (C) 2009, Wiley. Used with permission from Thompson CA, Huibregtse B, Poff B, Wilson G]. Time dependent vascular and myocardial responses of a second generation, small vessel, paclitaxel-eluting stent platform. Catheter Cardiovasc Interv. 2009;73(5):597-604. 


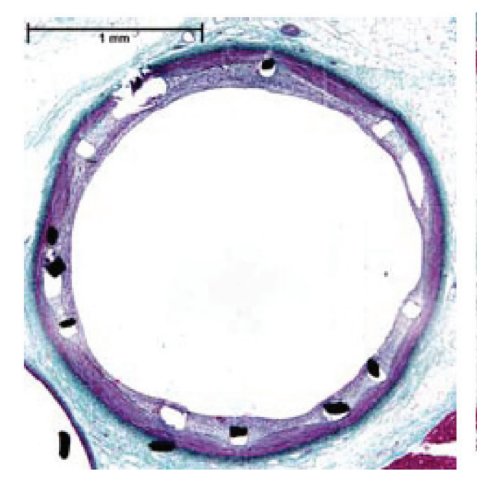

a. 3P676 LCX-OM1

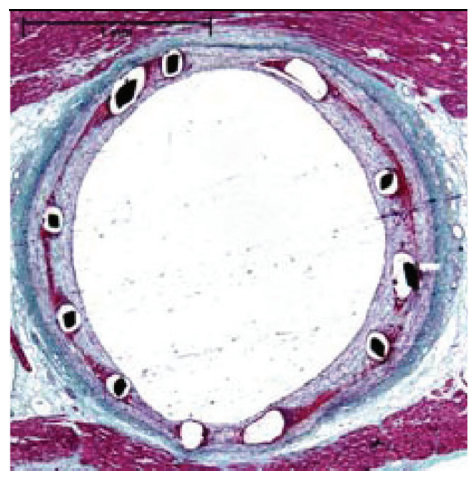

d. 3P666 RCA

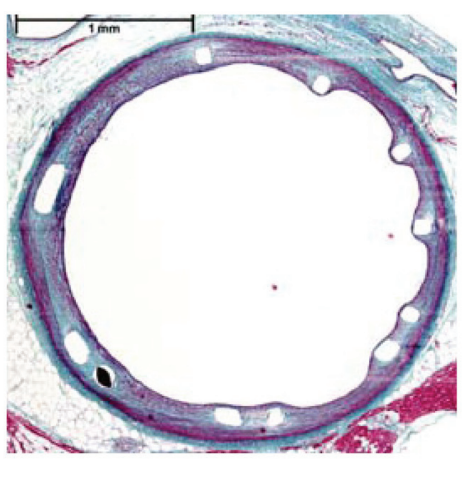

b. 3P657 LAD

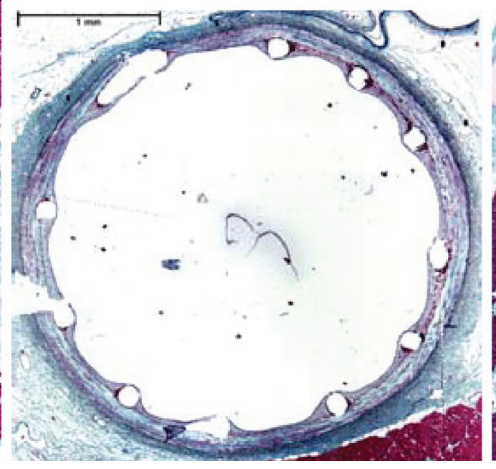

e. 3P660 LCX

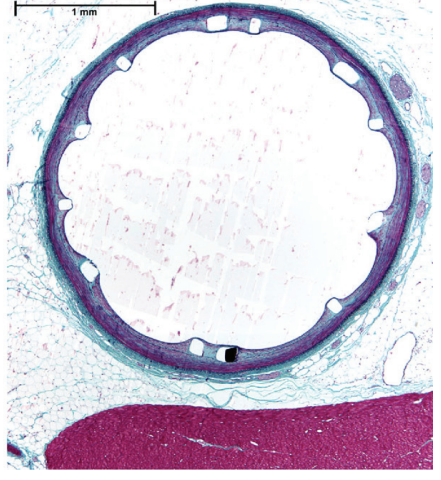

c. 3P711 LCX

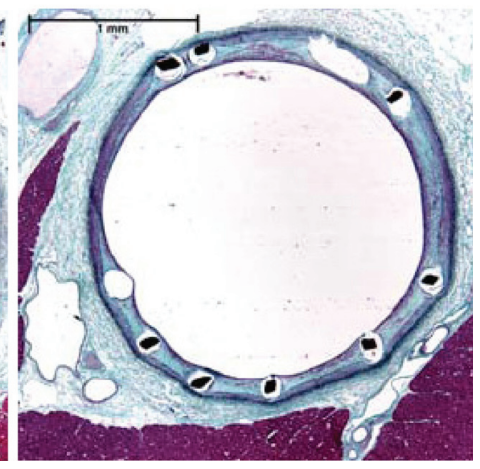

f. 3P696 LCX-OM2

Figure 4 Vascular compatibility using histologic analysis in a noninjured porcine model. Representative hematoxylin and eosin staining (40 $\times$ total magnification) of bare Liberté $(\mathbf{a}-\mathbf{c})$ and TAXUS Liberté Atom (d-f) mid-stent in cross section at 30 days (a, d), 90 days (b, e), and 180 days (c, f) postimplantation.

Copyright @ 2009, Wiley. Used with permission from Thompson CA, Huibregtse B, Poff B, Wilson GJ. Time dependent vascular and myocardial responses of a second generation, small vessel, paclitaxel-eluting stent platform. Catheter Cardiovasc Interv. 2009;73(5):597-604.

dedicated, prospective TAXUS Small Vessel trial are briefly described below.

\section{TAXUS IV trial}

The TAXUS IV study evaluated the safety and effectiveness of the TAXUS Express slow-release paclitaxel eluting stent system for treatment of de novo coronary artery lesions compared with an identical Express bare metal stent control. In a small vessel subgroup of patients with a reference vessel diameter $\leq 2.5 \mathrm{~mm}(\mathrm{n}=176)$, the TAXUS Express-treated patients had lower nine-month insegment restenosis $(10.2 \%$ versus $38.5, P<0.001)$ and nine-month target lesion revascularization $(3.4 \%$ versus 15.4, $P<0.001)$ rates than those treated with bare metal stents. ${ }^{37,38}$ The reduction in target lesion revascularization rate following treatment of small vessels $(<2.5 \mathrm{~mm})$ was maintained at three years, being $8.2 \%$ in the paclitaxeleluting stent group versus $26.9 \%$ in the bare metal stent group $(P<0.001){ }^{39}$

\section{TAXUS $V$ trial}

The TAXUS V de novo study evaluated the use of the TAXUS Express ${ }^{2}$ slow-release paclitaxel-eluting stent system versus an Express bare metal stent control in a more complex patient population consisting of de novo lesions, reference vessel diameter 2.25-4.0 $\mathrm{mm}$ and a lesion length of $10 \mathrm{~mm}-46 \mathrm{~mm}$. In the subgroup of patients $(\mathrm{n}=385)$ with small vessels (reference vessel diameter $\leq 2.5 \mathrm{~mm}$ ), lower revascularization rates were observed with paclitaxel-eluting stents when compared with bare metal stents. At two years, the target lesion revascularization rate in patients with treated small vessels was lower in paclitaxel-eluting stent-treated patients $(16.6 \%, \mathrm{n}=195)$ compared with those receiving a bare metal stent $(29.8 \%, P=0.002, \mathrm{n}=190) .{ }^{40}$ This benefit was maintained through five years $(20.6 \%$ versus $33.6 \%$, $P=0.004) .{ }^{41}$

A separate subset analysis of TAXUS V de novo patients receiving a $2.25 \mathrm{~mm}$ TAXUS Express stent (TAXUS Express Atom, $\mathrm{n}=108)$ versus a bare metal stent $(\mathrm{n}=95)$ was also 
performed. The nine-month angiographic results revealed improved instent late loss $(0.49 \pm 0.61$ versus $0.90 \pm 0.63 \mathrm{~mm}$, $P<0.001)$ and instent binary restenosis with paclitaxel-eluting stents $(24.7 \%$ versus $44.7 \%, P=0.007)$ than with bare metal stents (Table 1). The corresponding target lesion revascularization rate at nine months was lower in the paclitaxel-eluting stent group (10.4\%) than in the bare metal stent group $(21.5 \%$, $P=0.03)$, with comparable rates of death, myocardial infarction, and stent thrombosis between the two groups. ${ }^{21}$ These differences persisted through 12 months in patients treated with the $2.25 \mathrm{~mm}$ TAXUS Express stent. ${ }^{42}$ At three years, the target lesion revascularization rate was still numerically lower in patients receiving the $2.25 \mathrm{~mm}$ TAXUS Express stent (19.6\%) than in those with a bare metal stent $(27.1 \%, P=0.13)$, but the difference was no longer statistically significant. ${ }^{43}$

\section{TAXUSVI trial}

The TAXUS VI trial was a randomized, double-blind, controlled study assessing the safety and performance of the $1 \mu \mathrm{g} / \mathrm{mm}^{2}$ moderate-release formulation TAXUS Express paclitaxel-eluting stent in patients with high-risk (longer

Table I Safety and efficacy in patients receiving a $2.25 \mathrm{~mm}$ TAXUS Express Atom stent in the TAXUS V de novo study

\begin{tabular}{|c|c|c|c|}
\hline \multirow[t]{3}{*}{ Parameter } & \multicolumn{3}{|l|}{ TAXUS V } \\
\hline & \multicolumn{3}{|c|}{ Patients receiving a $2.25 \mathrm{~mm}$ stent } \\
\hline & $\begin{array}{l}\text { TAXUS Express } \\
\text { atom }(n=108)\end{array}$ & $\begin{array}{l}\text { BMS Express } \\
(n=95)\end{array}$ & $P$-value \\
\hline $\begin{array}{l}\text { Angiographic } \\
\text { follow-up }\end{array}$ & 9 Months & & \\
\hline $\begin{array}{l}\text { In-stent late } \\
\text { loss, mm }\end{array}$ & $0.49 \pm 0.61$ & $0.90 \pm 0.63$ & $<0.001$ \\
\hline $\begin{array}{l}\text { In-stent binary } \\
\text { restenosis }\end{array}$ & $24.7 \%$ & $44.7 \%$ & 0.007 \\
\hline $\begin{array}{l}\text { Clinical } \\
\text { follow-up }\end{array}$ & 9 Months & & \\
\hline TLR & $10.4 \%$ & $21.5 \%$ & 0.03 \\
\hline TVR & $16.0 \%$ & $24.7 \%$ & 0.16 \\
\hline MACE* & $18.9 \%$ & $26.9 \%$ & 0.23 \\
\hline Cardiac death & $1.9 \%$ & $1.1 \%$ & $>0.99$ \\
\hline $\mathrm{ST}^{\#}$ & $1.0 \%$ & $1.1 \%$ & $>0.99$ \\
\hline Follow-up 42 & I 2 Months & & \\
\hline TLR & $14.6 \%$ & $24.9 \%$ & 0.047 \\
\hline TVR & $22.6 \%$ & $30.4 \%$ & 0.26 \\
\hline MACE* & $26.4 \%$ & $32.6 \%$ & 0.35 \\
\hline Cardiac death & $2.8 \%$ & $1.2 \%$ & 0.63 \\
\hline $\mathrm{ST}^{\#}$ & $1.0 \%$ & $1.1 \%$ & $>0.99$ \\
\hline Follow-up ${ }^{43}$ & 36 Months & & \\
\hline TLR & 19.6 & 27.1 & 0.13 \\
\hline
\end{tabular}

Notes: *Includes cardiac death, myocardial infarction, and target vessel revascularization. "Per protocol definition.

Abbreviations: BMS, bare metal stent; TLR, target lesion revascularization; TVR, target vessel revascularization; MACE, major adverse cardiac event; ST, stent thrombosis. length) de novo coronary artery lesions. The TAXUS moderate-release investigational device used in this trial releases $33 \mu \mathrm{g}$ of paclitaxel per $3.0 \times 24 \mathrm{~mm}$ stent over 30 days (data from a preclinical animal model), approximately three times the dose released from the commercially available TAXUS slow-release stents. In the subgroup of patients $(n=124)$ with small vessels (reference vessel diameter $<2.5 \mathrm{~mm}$ ), the target lesion revascularization rate at nine months was significantly lower in patients receiving a paclitaxel-eluting stent $(5.0 \%)$ versus a bare metal stent $(29.7 \%, P<0.001) .{ }^{44}$ This benefit in target lesion revascularization rate was maintained at two years with the use of paclitaxel-eluting stents (8.3\%) versus bare metal stents $(29.5 \%, P=0.005),{ }^{45}$ and continued through five years (14.0\% versus $31.0 \%, P=0.02){ }^{46}$

\section{TAXUS ATLAS Small Vessel trial}

TAXUS ATLAS ( $\underline{A}$ multi-center, single-arm study of the TAXUS Liberté ${ }^{M}$-SR stent for the treatment of patients with de novo coronary artery lesions) Small Vessel was the first prospective TAXUS trial dedicated to investigation of TAXUS stent use in small vessels. The preclinical data described earlier is further supported by the results of the TAXUS ATLAS Small Vessel trial. The TAXUS ATLAS Small Vessel trial evaluated the safety and effectiveness of the $2.25 \mathrm{~mm}$ TAXUS Liberté (TAXUS Liberté Atom) stent in the treatment of de novo coronary artery lesions in patients with small vessels, compared with historic controls drawn from the TAXUS V randomized clinical trial. A total of 261 patients, with a reference vessel diameter 2.2-2.5 mm (visual estimate), from 23 investigational sites were enrolled to receive a $2.25 \mathrm{~mm}$ TAXUS Liberté stent. The trial had two prespecified control groups, ie, a bare metal stent control $(n=155)$ comprising TAXUS V patients treated with either a $2.25 \mathrm{~mm}$ or $2.5 \mathrm{~mm}$ bare metal Express stent or a TAXUS Express control $(\mathrm{n}=75)$ comprised ofTAXUS V patients treated with a 2.25 mm TAXUS Express (TAXUS Express Atom) stent. Patients received dual antiplatelet therapy (clopidogrel or ticlopidine and aspirin) for a minimum of six months (aspirin for a minimum of nine months), and were scheduled for quantitative coronary angiography at nine months. The study met its primary nine-month superiority endpoint compared with bare metal stents and the nine-month noninferiority endpoint compared with TAXUS Express for insegment $\%$ diameter stenosis.

The nine-month angiographic results revealed improved instent late loss $(0.28 \pm 0.45$ versus $0.84 \pm 0.57 \mathrm{~mm}$, $P<0.001)$ and instent binary restenosis $(13.0 \%$ versus $38.1 \%, P<0.001)$ with the paclitaxel-eluting stent than with the bare metal stent control. ${ }^{47,48}$ The corresponding target 
lesion revascularization rate at nine months was lower in the paclitaxel-eluting stent group (5.8\%) than in the bare metal stent group $(17.6 \%, P<0.001)$, with comparable rates of death, myocardial infarction, and stent thrombosis between the two groups. ${ }^{47}$

When compared with the $2.25 \mathrm{~mm}$ TAXUS Express stent, the $2.25 \mathrm{~mm}$ TAXUS Liberté stent significantly reduced the nine-month angiographic rates of both instent late loss ( $0.44 \pm 0.61$ versus $0.28 \pm 0.45 \mathrm{~mm}, P=0.03)$ and instent binary restenosis $(25.9 \%$ versus $13.0 \%, P=0.02)$ as well as the nine-month target lesion revascularization rate $(13.7 \%$ versus $5.8 \%, P=0.02$ ) in the small vessel population ${ }^{47}$ (Table 2 ). The reduction in target lesion revascularization rate with the TAXUS Liberté compared with the TAXUS Express control was maintained at 12 months $(6.1 \%$ versus $16.9 \%, P=0.004)$, at two years $(8.2 \%$ versus $20.3 \%, P=0.005)$, and at three years ( $10.0 \%$ versus $22.1 \%, P=0.008)$, with similar safety outcomes

Table 2 Principle safety and effectiveness data of the $2.25 \mathrm{~mm}$ TAXUS Liberté Atom stent in small vessels in the TAXUS ATLAS Small Vessel trial

\begin{tabular}{|c|c|c|c|}
\hline \multirow[t]{3}{*}{ Parameter } & \multicolumn{3}{|c|}{ TAXUS ATLAS Small Vessel } \\
\hline & \multicolumn{3}{|c|}{ Case-matched (2.2-2.5 mm RVD) patients } \\
\hline & $\begin{array}{l}\text { TAXUS Liberté } \\
\text { Atom }(n=26 \mathrm{I})\end{array}$ & $\begin{array}{l}\text { TAXUS Express } \\
\text { Atom }(n=75)\end{array}$ & $P$-value \\
\hline $\begin{array}{l}\text { Angiographic } \\
\text { follow-up }{ }^{47}\end{array}$ & 9 Months & & \\
\hline $\begin{array}{l}\text { In-stent late } \\
\text { loss, mm }\end{array}$ & $0.28 \pm 0.45$ & $0.44 \pm 0.61$ & 0.03 \\
\hline $\begin{array}{l}\text { In-stent binary } \\
\text { restenosis }\end{array}$ & $13.0 \%$ & $25.9 \%$ & 0.02 \\
\hline $\begin{array}{l}\text { Clinical } \\
\text { follow-up }{ }^{47}\end{array}$ & 9 Months & & \\
\hline TLR & $5.8 \%$ & $13.7 \%$ & 0.02 \\
\hline TVR & $10.1 \%$ & $17.8 \%$ & 0.07 \\
\hline MACE* & $12.8 \%$ & $20.5 \%$ & 0.10 \\
\hline Cardiac death & $0.8 \%$ & $2.7 \%$ & 0.46 \\
\hline $\mathrm{ST}^{\#}$ & $0.4 \%$ & $1.4 \%$ & 0.39 \\
\hline Follow-up ${ }^{50}$ & 24 Months $^{\S}$ & & \\
\hline TLR & $8.2 \%$ & $20.3 \%$ & 0.005 \\
\hline TVR & $12.8 \%$ & $26.1 \%$ & 0.007 \\
\hline MACE & $16.5 \%$ & $30.4 \%$ & 0.01 \\
\hline Cardiac death & $2.1 \%$ & $4.3 \%$ & 0.38 \\
\hline $\mathrm{ST}^{\#}$ & $0.8 \%$ & $1.5 \%$ & 0.52 \\
\hline Follow-up ${ }^{51}$ & 36 Months $^{\S}$ & & \\
\hline TLR & $10.0 \%$ & $22.1 \%$ & 0.008 \\
\hline TVR & $15.2 \%$ & $27.9 \%$ & 0.02 \\
\hline MACE* & $19.5 \%$ & $32.4 \%$ & 0.03 \\
\hline Cardiac death & $2.6 \%$ & $4.4 \%$ & 0.43 \\
\hline $\mathrm{ST}^{\#}$ & $1.4 \%$ & $1.5 \%$ & $>0.99$ \\
\hline
\end{tabular}

Notes: *Includes cardiac death, myocardial infarction, and target vesse revascularization. "Academic Research Consortium definite/probable definition ${ }^{\S}$ Consists of patients who received a study stent at baseline.

Abbreviations: TLR, target lesion revascularization; TVR, target vessel revascularization; MACE, major adverse cardiac event; ST, stent thrombosis. throughout the small vessel population. ${ }^{49-51}$ An independent multivariate analysis revealed that treatment with the TAXUS Liberté significantly reduced the risk of target lesion revascularization versus the TAXUS Express through three years (hazard ratio $0.34 ; 95 \%$ confidence interval $0.17-0.66, P=0.001) .{ }^{51}$

\section{Summary}

The three TAXUS trial subgroup analyses and the dedicated TAXUS ATLAS Small Vessel trial demonstrate an overall consistent and sustained lowering of late loss and angiographic and clinical restenosis with the TAXUS stents compared with bare metal stent controls in small vessels.

\section{Registry data with TAXUS stents in small vessels}

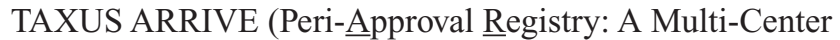
Safety Surveillance Program) included two consecutively enrolling, multicenter safety surveillance registries in the US (ARRIVE 1 and ARRIVE 2). The program captured usage patterns and two-year outcomes with the TAXUS Express stent in 7492 patients treated during routine practice, including 4794 patients who would have been excluded from pivotal randomized controlled trials. ${ }^{52,53}$ In the combined registry cohort of patients with reference vessel diameter $<2.5 \mathrm{~mm}$ $(\mathrm{n}=251)$, target lesion revascularization was $7.5 \%$ in the first year and $1.3 \%$ in the second year. In the ARRIVE 1 small vessel subgroup (reference vessel diameter $\leq 2.5 \mathrm{~mm}, \mathrm{n}=743$ ) target lesion revascularization was $6.6 \%$ after 12 months and $2.7 \%$ in the second year.

TAXUS OLYMPIA was a multicenter, prospective, global registry capturing safety and clinical outcomes in patients receiving the TAXUS Liberté stent in routine clinical practice. From a preliminary population of 22,345 patients, the 12-month target lesion revascularization rate was $2.8 \%$ and composite cardiac event (cardiac death, myocardial infarction, and target vessel revascularization) rate was $4.8 \%$ in treated patients $(\mathrm{n}=2460)$ with small vessels $(<2.5 \mathrm{~mm}) .{ }^{54}$

The TAXUS ARRIVE and TAXUS OLYMPIA registries have reported low safety event rates and acceptable clinical outcomes when treating small vessels with either TAXUS Express or TAXUS Liberté stents. These outcomes observed in routine interventional practice further support the findings from the TAXUS randomized clinical trials.

\section{Sirolimus-eluting $\mathbf{2 . 2 5} \mathbf{~ m m}$ stent in small vessels}

In addition to the TAXUS Express Atom and the TAXUS Liberté Atom stents, a third $2.25 \mathrm{~mm}$ drug-eluting stent that has 
received FDA approval is the CYPHER $^{\circledR}$ sirolimus-eluting BX-velocity stent system (Cordis Corporation, Bridgewater, NJ). The CYPHER Mini (2.25 mm) is mounted on a rapid exchange stent delivery system with a crimped profile of 0.044 inches. The pivotal trial for approval of the $2.25 \mathrm{~mm}$ CYPHER drug-eluting stent was SIRIUS 2.25, the primary endpoint of which was six-month binary restenosis, revealed to be at a rate of $16.9 \%$, with a target lesion revascularization rate at six months of $4.0 \%$ compared with $15.0 \%$ in historic bare metal stent controls. ${ }^{55}$ A comparison of target lesion revascularization rates between the CYPHER $2.25 \mathrm{~mm}$ stent in SIRIUS 2.25 and the TAXUS Liberté $2.25 \mathrm{~mm}$ stent from the TAXUS ATLAS Small Vessel trial reveal numerically similar outcomes at 12 months $(7.0 \%$ versus $6.1 \%)$ and at two years $(9.0 \%$ versus $8.2 \%) .{ }^{49,50,56}$ Numerically similar target lesion revascularization rates were also observed with the TAXUS Liberté Atom and the CYPHER stent in trials with vessels $\leq 2.75 \mathrm{~mm}$ in diameter. ${ }^{57,58}$ Target lesion revascularization with TAXUS Liberté $2.25 \mathrm{~mm}$ at 12 months $(6.1 \%)^{48}$ and at 24 months $(8.2 \%)^{49}$ compared favorably with the sirolimus-eluting stent at 12 months $(6.6 \%)^{56}$ and at 24 months $(7.9 \%) .{ }^{57}$ Definitive conclusions cannot be drawn from an indirect comparison between sirolimus- and paclitaxel-eluting stents because appropriately powered clinical trials directly comparing the TAXUS Liberté Atom stent and the CYPHER mini stent in small vessels have not been reported.

\section{Conclusions}

In the treatment of small coronary vessels, drug-eluting stents have provided consistently improved outcomes compared with bare metal stents across different stent platforms and antirestenotic drugs. The safety and performance of the TAXUS paclitaxel-eluting stent have been demonstrated with preclinical, clinical trial, and registry data. In particular, the improved design of the second-generation, thin-strut $2.25 \mathrm{~mm}$ TAXUS Liberte Atom stent compared with the $2.25 \mathrm{~mm}$ TAXUS Express Atom stent results in less revascularization over time, without increasing mortality or myocardial infarction. A third-generation stent, TAXUS Element ${ }^{\mathrm{TM}}$, is currently being investigated for use in small vessels in the PERSEUS (A Prospective Evaluation in a Randomized Trial of the Safety and Efficacy of the Use of the TAXUS ${ }^{\circledR}$ Element $^{\mathrm{TM}}$ Paclitaxel-Eluting Coronary Stent System for the Treatment of De Novo Coronary Artery Lesions) Small Vessel trial and has demonstrated 12-month superiority in efficacy to the bare metal Express stent control. ${ }^{59,60}$

\section{Disclosure}

JFG has received research grant support from Boston Scientific; BAH and KDD are employees of and shareholders in Boston Scientific Corporation. This study was supported by Boston Scientific Corporation.

\section{References}

1. Lau KW, Hung JS, Sigwart U. The current status of stent placement in small coronary arteries $<3.0 \mathrm{~mm}$ in diameter. $J$ Invasive Cardiol. 2004;16(8):411-416.

2. Wong P, Lau KW, Lim YL, Oesterle SN. Stent placement for nonSTRESS/BENESTENT lesions: A critical review. Catheter Cardiovasc Interv. 2000;51(2):223-233.

3. Colombo A, Chieffo A. Drug-eluting stent update 2007: Part III: Technique and unapproved/unsettled indications (left main, bifurcations, chronic total occlusions, small vessels and long lesions, saphenous vein grafts, acute myocardial infarctions, and multivessel disease). Circulation. 2007;116(12):1424-1432.

4. Elezi S, Kastrati A, Neumann F-J, Hadamitzky M, Dirschinger J, Schomig A. Vessel size and long-term outcome after coronary stent placement. Circulation. 1998;98(18):1875-1880.

5. Al Suwaidi J, Berger PB, Holmes DR Jr. Coronary artery stents. JAMA. 2000;284(14):1828-1836.

6. Mehilli J, Kastrati A, Dirschinger J, Bollwein H, Neumann F-J, Schomig A. Differences in prognostic factors and outcomes between women and men undergoing coronary artery stenting. JAMA. 2000; 284(14):1799-1805.

7. Serruys PW, de Jaegere P, Kiemeneij F, et al. A comparison of balloonexpandable-stent implantation with balloon angioplasty in patients with coronary artery disease. $N$ Engl J Med. 1994;331(8):489-495.

8. Fischman DL, Leon MB, Baim DS, et al. A randomized comparison of coronary-stent placement and balloon angioplasty in the treatment of coronary artery disease. $N$ Engl J Med. 1994;331(8): 496-501.

9. Kastrati A, Schomig A, Dirschinger J, et al. A randomized trial comparing stenting with balloon angioplasty in small vessels in patients with symptomatic coronary artery disease. Circulation. 2000;102(21):2593-2598.

10. Moreno R, Fernández C, Alfonso F, et al. Coronary stenting versus balloon angioplasty in small vessels: A meta-analysis from 11 randomized studies. J Am Coll Cardiol. 2004;43(11):1964-1972.

11. Agostoni P, Biondi-Zoccai GG, Gasparini GL, et al. Is bare-metal stenting superior to balloon angioplasty for small vessel coronary artery disease? Evidence from a meta-analysis of randomized trials. Eur Heart J. 2005;26(9):881-889.

12. Schofer J, Schluter M, Gershlick AH, et al. Sirolimus-eluting stents for treatment of patients with long atherosclerotic lesions in small coronary arteries: Double-blind, randomised controlled trial (E-SIRIUS). Lancet. 2003;362(9390):1093-1099.

13. Brodie BR, Stuckey T, Downey W, et al. Outcomes and complications with off-label use of drug-eluting stents. Results from the STENT (Strategic Transcatheter Evaluation of New Therapies) Group. JACC Cardiovasc Interv. 2008;1(4):405-414.

14. Whang Y-J, Kim H-S, Kim K-M, et al. The efficacy of drug eluting stents on restenosis reduction in small coronary arteries. Korean Circ J. 2006;36(6):450-457.

15. Ramsdale DR, Rao A, Asghar O, Ramsdale KA, McKay E. Late outcomes after drug-eluting stent implantation in "real- world" clinical practice. J Invasive Cardiol. 2008;20(10):493-500.

16. Bucalo R, Capranzano P, Conti G, et al. Sirolimus versus paclitaxeleluting stents in small coronary vessels: Long-term outcomes from a single-center registry. $J$ Cardiovasc Med (Hagerstown). 2010;11(5):365-368. 
17. Scott NA. Restenosis following implantation of bare metal coronary stents: Pathophysiology and pathways involved in the vascular response to injury. Adv Drug Deliv Rev. 2006;58(3):358-376.

18. Hoffmann R, Mintz GS, Dussaillant GR, et al. Patterns and mechanisms of instent restenosis: A serial intravascular ultrasound study. Circulation. 1996;94(6):1247-1254.

19. Chieffo A, Foglieni C, Nodari RL, et al. Histopathology of clinical coronary restenosis in drug-eluting versus bare metal stents. Am J Cardiol. 2009;104(12):1660-1667.

20. Moses JW, Leon MB, Popma JJ, et al. Sirolimus-eluting stents versus standard stents in patients with stenosis in a native coronary artery. N Engl J Med. 2003;349(14):1315-1323.

21. Stone GW, Ellis SG, Cannon L, et al. Comparison of a polymer-based paclitaxel-eluting stent with a bare metal stent in patients with complex coronary artery disease: A randomized controlled trial. JAMA. 2005;294(10):1215-1223.

22. Briguori C, Sarais C, Pagnotta $\mathrm{P}$, et al. Instent restenosis in small coronary arteries: Impact of strut thickness. J Am Coll Cardiol. 2002;40(3):403-409.

23. Kereiakes DJ. Coronary small-vessel stenting in the era of drug elution. Rev Cardiovasc Med. 2004;5 Suppl 2:S34-S45.

24. Blagosklonny MV, Darzynkiewicz Z, Halicka HD, et al. Paclitaxel induces primary and postmitotic G1 arrest in human arterial smooth muscle cells. Cell Cycle. 2004;3(8):1050-1056.

25. Wullschleger $\mathrm{S}$, Loewith $\mathrm{R}$, Hall MN. TOR signaling in growth and metabolism. Cell. 2006;124(3):471-484.

26. Rowinsky EK, Donehower RC. Paclitaxel (taxol). N Engl J Med. 1995; 332(15):1004-1014.

27. Axel DI, Kunert W, Goggelmann C, et al. Paclitaxel inhibits arterial smooth muscle cell proliferation and migration in vitro and in vivo using local drug delivery. Circulation. 1997;96(2):636-645.

28. Carter AJ, Farb A, Gould KE, Taylor AJ, Virmani R. The degree of neointimal formation after stent placement in atherosclerotic rabbit iliac arteries is dependent on the underlying plaque. Cardiovasc Pathol. 1999;8(2):73-80.

29. Hiatt BL, Ikeno F, Yeung AC, Carter AJ. Drug-eluting stents for the prevention of restenosis: In quest for the holy grail. Catheter Cardiovasc Interv. 2002;55(3):409-417.

30. Kamath KR, Barry JJ, Miller KM. The Taxus(TM) drug-eluting stent: A new paradigm in controlled drug delivery. Adv Drug Deliv Rev. 2006;58(3):412-436.

31. Pache J, Kastrati A, Mehilli J, et al. Intracoronary stenting and angiographic results: Strut thickness effect on restenosis outcome (ISARSTEREO-2) trial. J Am Coll Cardiol. 2003;41(8):1283-1288.

32. Kastrati A, Mehilli J, Dirschinger J, et al. Intracoronary stenting and angiographic results: Strut thickness effect on restenosis outcome (ISAR-STEREO) trial. Circulation. 2001;103(23): 2816-2821.

33. Thompson CA, Huibregtse B, Poff B, Wilson GJ. Time dependent vascular and myocardial responses of a second generation, small vessel, paclitaxel-eluting stent platform. Catheter Cardiovascular Interv. 2009;73(5):597-604.

34. Joner M, Finn AV, Farb A, et al. Pathology of drug-eluting stents in humans: Delayed healing and late thrombotic risk. J Am Coll Cardiol. 2006;48(1):193-202.

35. Godino C, Furuichi S, Latib A, et al. Clinical and angiographic follow-up of small vessel lesions treated with paclitaxel-eluting stents (from the TRUE Registry). Am J Cardiol. 2008;102(8):1002-1008.

36. Rodriguez-Granillo GA, Valgimigli M, Garcia-Garcia HM, et al. Oneyear clinical outcome after coronary stenting of very small vessels using $2.25 \mathrm{~mm}$ sirolimus- and paclitaxel-eluting stents: A comparison between the RESEARCH and T-SEARCH registries. J Invasive Cardiol. 2005;17(8):409-412.

37. Stone GW, Ellis SG, Cox DA, et al. A polymer-based, paclitaxeleluting stent in patients with coronary artery disease. $N$ Engl J Med. 2004;350(3):221-231.
38. Stone GW. The pivotal, prospective, randomized trial of the slow-rate release polymer-based paclitaxel-eluting TAXUSTM stent. Presented at Transcatheter Cardiovascular Therapeutics meeting, 2003 Sept 15-19, Washington, DC.

39. Stone GW. The pivotal U S study of the slow-rate release, polymerbased, paclitaxel-eluting TAXUS stent in patients with with de novo coronary lesions: 3-year clinical results of the TAXUS-IV trial. Presented at Transcatheter Cardiovascular Therapeutics meeting, 2005 Oct 17-21, Washington, DC.

40. Ellis SG. Safety and efficacy of the polymer-based, paclitaxel-eluting TAXUS stent: 2-year clinical results from the TAXUS-V de novo trial. Presented at Transcatheter Cardiovascular Therapeutics meeting, October 22-27, 2006, Washington, DC.

41. Ellis SG, Cannon LA, Mann T, et al. Final 5-Year outcomes from the TAXUS V de novo trial: Long-term safety and effectiveness of the paclitaxel-eluting TAXUS stent in complex lesions. Presented at Transcatheter Cardiovascular Therapeutics meeting, 2009 Sep 21-25, San Francisco, CA.

42. Stone GW, Mann T, Ellis SG, et al. Beneficial effects of the $2.25 \mathrm{~mm}$ paclitaxel-eluting TAXUS stent in patients with lesions in small coronary arteries: 9 and 12 month results from the TAXUS-V trial. Presented at American Heart Association meeting, 2005; Dallas, TX.

43. Ellis SG, Cannon LA, Mann T, et al. Long-term safety and efficacy of the paclitaxel-eluting TAXUS stent in eluting TAXUS stent in complex lesions: Three-year clinical results from the TAXUS V de novo trial. Presented at Transcatheter Cardiovascular Therapeutics meeting, 2007 October 20-25, Washington, DC.

44. Dawkins KD, Grube E, Guagliumi G, et al. Clinical efficacy of polymer-based paclitaxel-eluting stents in the treatment of complex, long coronary artery lesions from a multicenter, randomized trial: Support for the use of drug-eluting stents in contemporary clinical practice. Circulation. 2005;112(21):3306-3313.

45. Grube E, Dawkins KD, Guagliumi G, et al. TAXUS VI 2-year follow-up: randomized comparison of polymer-based paclitaxel-eluting with bare metal stents for treatment of long, complex lesions. Eur Heart J. 2007 ;28(21):2578-2582.

46. Grube E, Dawkins K, Guagliumi G, et al. TAXUS VI final 5-year results: A multicentre, randomised trial comparing polymer-based moderate-release paclitaxel-eluting stent with a bare metal stent for treatment of long, complex coronary artery lesions. EuroIntervention. 2009;4(5):572-577.

47. Turco MA, Ormiston JA. TAXUS ATLAS small vessel and long lesion: First report of nine-month clinical and angiographic results. Presented at Transcatheter Cardiovascular Therapeutics meeting, 2007 Oct 20-25, Washington, DC.

48. Ormiston JA, Turco MA, Mandinov L, et al. TAXUS ATLAS small vessel 9-month clinical and angiographic outcomes: Evaluation of the TAXUS Liberté $2.25 \mathrm{~mm}$ stent in small vessels. Presented at American Heart Association meeting, 2007, Orlando, FL.

49. Turco MA, Ormiston JA, Popma JJ, et al. Reduced risk of restenosis in small vessels and reduced risk of myocardial infarction in long lesions with the new thin-strut TAXUS Liberte Stent. 1-year results from the TAXUS ATLAS Program. JACC Cardiovasc Interv. 2008;1(6):699-709.

50. Ormiston JA, Turco MA, Mandinov L, et al. Durable benefit of TAXUS Liberté versus TAXUS Express in Small Vessels and Long Lesions in the TAXUS ATLAS Small Vessel and TAXUS ATLAS Long Lesion trials. Presented at Transcatheter Cardiovascular Therapeutics meeting, 2008 Oct 12-17, Washington, DC.

51. Turco MA, Ormiston JA, Hall JJ, et al. TAXUS ATLAS Small Vessel and TAXUS ATLAS Long Lesion trials: Long-term benefit of TAXUS Liberté versus TAXUS Express in small vessels and long lesions. Presented at Transcatheter Cardiovascular Therapeutics meeting, 2009 Sep 21-25, San Francisco, CA.

52. Lasala JM, Cox DA, Lewis SJ, et al. Expanded use of the TAXUS Express stent: Two-year safety insights from the 7,500 patient ARRIVE Registry programme. EuroIntervention. 2009;5(1):67-77. 
53. Lasala JM, Cox DA, Dobies D, et al. Usage patterns and 2-year outcomes with the TAXUS express stent: Results of the US ARRIVE 1 registry. Catheter Cardiovasc Interv. 2008;72(4):433-445.

54. Ahmed WH, Thomas MR, Mendiz OA, Mascioli SR, Dawkins KD. The OLYMPIA TAXUS Liberté Registry: One-year outcomes in high-risk lesion subgroups and patients with serious comorbid conditions. Presented at Transcatheter Cardiovascular Therapeutics meeting, 2008 Oct 12-17, Washington, DC.

55. Moses JW, Nikolsky E, Mehran R, et al. Safety and efficacy of the 2.25-mm sirolimus-eluting BX velocity stent in the treatment of patients with de novo native coronary artery lesions: The SIRIUS 2.25 trial. Am J Cardiol. 2006;98(11):1455-1460.

56. Nikolsky E, Moses JW, Mehran R, et al. Long-term follow-up after implantation of the $2.25 \mathrm{~mm}$ sirolimus-eluting BX Velocity ${ }^{\mathrm{TM}}$ stent in patients with native coronary artery lesions. Presented at Transcatheter Cardiovascular Therapeutics meeting, 2006 Oct 22-27, Washington, DC.
57. Mehilli J, Dibra A, Kastrati A, et al. Randomized trial of paclitaxeland sirolimus-eluting stents in small coronary vessels. Eur Heart J. 2006;27(3):260-266

58. Menozzi A, Solinas E, Ortolani P, et al. Twenty-four months clinical outcomes of sirolimus-eluting stents for the treatment of small coronary arteries: The long-term SES-SMART clinical study. Eur Heart J. 2009;30(17):2095-2101.

59. Allocco D, Cannon L, Britt A, et al. A prospective evaluation of the safety and efficacy of the TAXUS Element paclitaxel-eluting coronary stent system for the treatment of de novo coronary artery lesions: Design and statistical methods of the PERSEUS clinical program. Trials. 11(1):1.

60. Kereiakes DJ, Cannon LA, Feldman RL, et al. TAXUS PERSEUS: A novel platinum chromium, thin-strut TAXUS Element stent for the treatment of de novo coronary stenoses. Presented at American College of Cardiology/Innovation in Intervention Summit, 2010 Mar 14-16, Atlanta, GA.

\section{Publish your work in this journal}

Medical Devices: Evidence and Research is an international, peerreviewed, open access journal that focuses on the evidence, technology, research, and expert opinion supporting the use and application of medical devices in the diagnosis, treatment and management of clinical conditions and physiological processes. The identification of novel devices and optimal use of existing devices which will lead to improved clinical outcomes and more effective patient management and safety is a key feature. The manuscript management system is completely online and includes a quick and fair peer-review system. Visit http://www. dovepress.com/testimonials.php to read real quotes from authors. 